\title{
Effect of Endosseous Implants on the Impact Fracture Strength of the Edentulous Mandible
}

\author{
Hiroshi Kawazu and Jun Shimada*
}

Static load tests and impact fracture tests were carried out on edentulous mandibles to evaluate the effect of drill hole preparations made in the bone for implant fixtures. Deformation was measured in the mandibles with strain gauges before the drill holes were made, after monocortical preparation of the bone, after bicortical preparation, and after the Brånemark implant fixtures were tightened into the preparations.

Compared with the monocortical implant preparation, the bicortical preparation produced greater deterioration in the resistance of the mandible to external forces, and greater loss in impact fracture strength. However, there was a slight improvement in the strength of the mandibles after acquisition of osseointegration.

\section{Introduction}

Implant dentistry has in recent years received much attention as a method of improving cases where adequate restoration of masticatory function could not be attained by conventional removable prosthodontics. As a result of considerable basic research ${ }^{1 \sim 3}$ and investigations of clinical applications ${ }^{4 \sim 7)}$, implant dentistry has now acquired an important place in the prosthetic treatment of missing teeth.

However, there have been reports of unforeseen fractures in the region where the bone was prepared to receive the implant, especially when the artificial root implant was placed in the mandible ${ }^{8}$. This is thought to arise because of the cylindrical defect created in the bone when an artificial root several millimeters in

Post-Doctoral Institute, Meikai University, School of Dentistry

* First Department of Oral Surgery, Meikai University, School of Dentistry diameter is implanted, resulting in a defect in the bone itself and a decrease in the strength of the original mandible.

Nonetheless, there have been no reports of investigations into the dynamics of decreases in the strength of the mandible resulting from placement of these implants. Therefore, we report here the significant results we obtained in our experiments into the effect on the impact strength when artificial root type Brånemark implants were placed in edentulous mandibles.

\section{Materials and Methods}

\section{Materials}

We used 25 Indo-European edentulous mandibles prepared by Habara Skeletal Specimen Research Institute, Tokyo, Japan. In selecting the specimens, we referred to the recommended indications for Brånemark Implants and used only mandibles with a height of bone of at least $15 \mathrm{~mm}$ between the mental foramina. Although the age and gender of the specimens were 
unknown, we eliminated those that appeared to have excessive bone resorption or rough surfaces, and those suspected of having pathological lesions.

Static load tests were carried out on five of the mandibles, followed by impact fracture tests on the remaining twenty.

\section{Static Load Test}

Static load tests were done to quantitatively measure how changes in the strain distribution arose as a result of the bone preparation where the implant was placed.

Strain gauges were fixed to each of the five test mandibles and the static strain was measured around the region where the implant was placed under each of the following four conditions. First there was no preparation of the mandible (Group P). Then the implant preparation was made by placing a drill hole in the monocortical bone to a depth of $10 \mathrm{~mm}$ (Group M). Next implant preparations were placed by making drill holes to a depth of 15 to $18 \mathrm{~mm}$ into the bicortical bone (Group B). Lastly, the implant was actually placed after preparation of the drill holes in the bicortical bone (Group F).

The Branemark Implant System Manual ${ }^{9)}$ was followed in preparing the mandible for the implant, i. e., drilling the hole in the bone. After placement of a starting point with a round bur (Fig. 1), the hole was made with a $2 \mathrm{~mm}$ diameter twist drill, a pilot drill, and a $3 \mathrm{~mm}$ diameter twist drill, in that order. The last steps were the countersink and screw tap preparations (Fig. 2). Five implant preparations were placed between the two mental foramina, one at the midline and two each on either side, with $10 \mathrm{~mm}$ between the center of each hole.

The implant fixtures placed in the preparations were the Branemark Implant System (Nobel Biocare, Sweden, Fig. 3). In order to

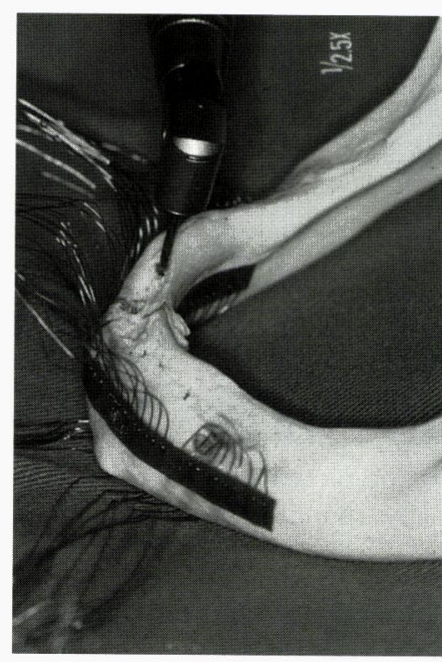

Fig. 1 Bone preparation before placement of the implant fixture.

recreate osseointegration of the fixture, i.e., fixation of the implant to the bone, the experimental apparatus was prepared by coating the surface of the fixture with fast-setting adhesive resin cement before placement, and then testing that it was impossible to turn the implant by hand with a wrench after the cement had set.

Detection of the strain was carried out with KFC-2-D9-11 stress concentration measurement gauges (Kyowa Electric, Tokyo, Japan). Strain gauges were placed symmetrically midway between the upper and lower borders, five on the facial surface (Fig. 4) and three on the lingual (Fig.5). Since each gauge had five measurement points, there was a total of 25 points on the facial and 15 on the lingual, making it possible to carry out measurements over the entire region of the implant preparations. The gauges were $2 \mathrm{~mm}$ in length, had a gauge factor of $2.12 \pm 1 \%$, and a resistance of $120.0 \pm 0.6 \Omega$.

The static load was carried out with the Shimazu S-500 Autograph multi-purpose test device (Shimazu Manufacturing, Tokyo, 


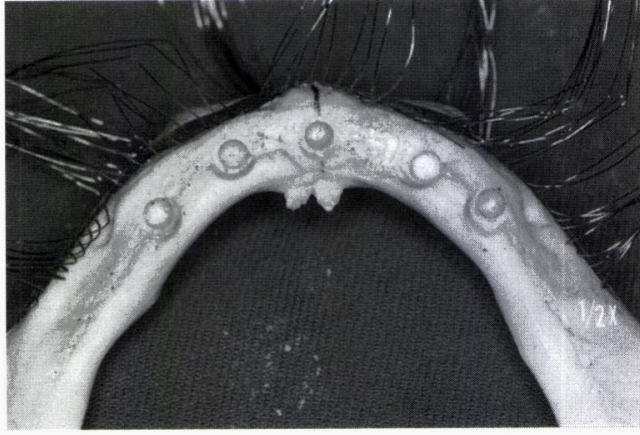

Fig. 2 Completed implant preparations in the mandible.

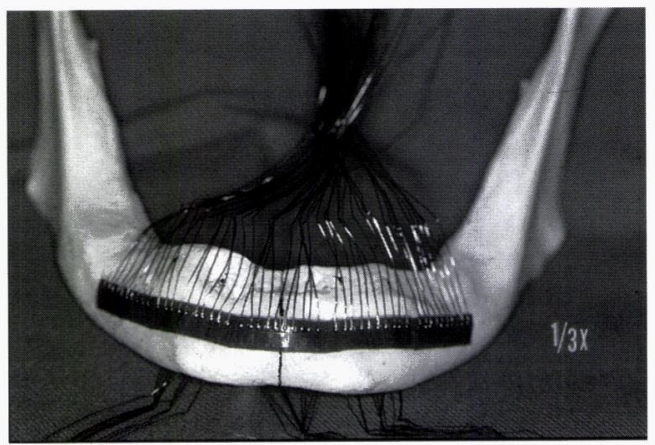

Fig. 4 Placement of strain gauges on the buccal surface of a test mandible.

Japan) hereafter referred to as the S-500. Measurements were carried out at $2 \mathrm{~kg}$ increments between 0 and $10 \mathrm{~kg}$ at a speed of $5 \mathrm{~mm}$ perminute. The strain at $10 \mathrm{kgf}$ load was calculated by the linear regression method and was assumed to be the measured value. Support of the test mandible was carried out by placing it directly with pin support on a special mandible support apparatus fixed to the S-500 pressure plate, and the load was applied through a bending punch to the gnathion by the fall of the $\mathrm{S}^{-}$ 500 load cell (Fig. 6). An AT Scanner USB51A and a Data Collection System UCAM10-A (both from Kyowa Electric) were used for strain measurements, data collection and computations. The value for the strain was assumed to be the average obtained from the results for the five mandibles. Statistical analyses and

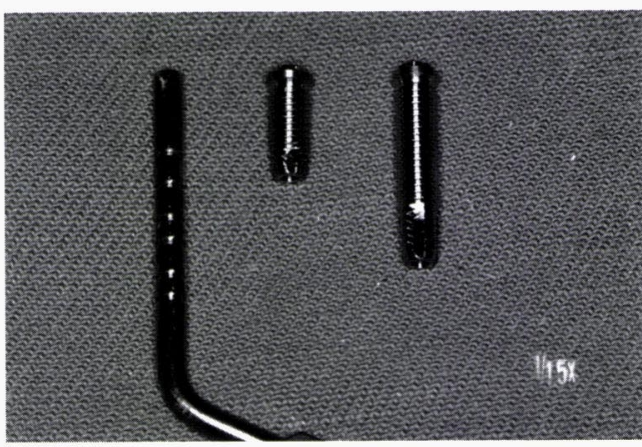

Fig. 3 Brånemark implant fixtures used in this study.

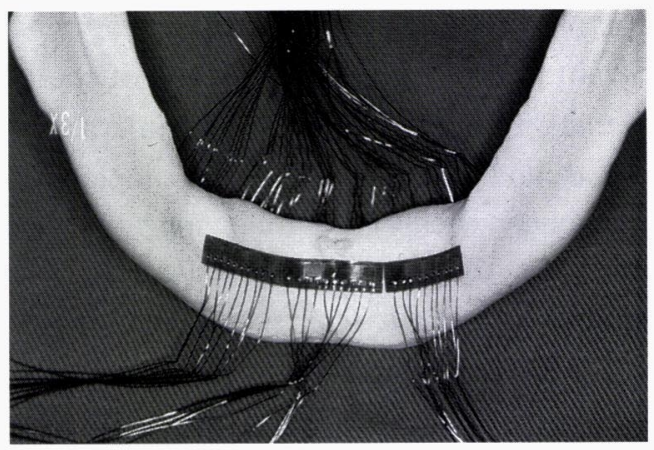

Fig. 5 Placement of strain gauges on the lingual surface of a test mandible.

examinations were carried out.

\section{Impact Fracture Test}

The impact fracture test was undertaken to understand how changes occur in the impact fracture strength of the mandible as a result of the preparation for the implant. The experiment was carried out and the results compared where, similar to the situation with the static load test, 20 edentulous mandibles were divided into four groups of five each. These included the one group with no preparation for the implants $(\mathrm{P})$, a group where a drill hole was made $10 \mathrm{~mm}$ into the monocortical bone (M), a group where drill holes were made to a depth of 15 to $18 \mathrm{~mm}$ into the bicortical bone (B), and a group where the fixture was actually placed after preparation of the drill holes in the bicor- 


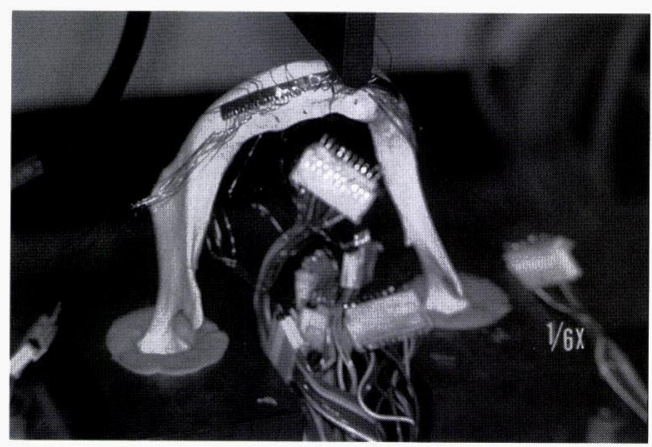

Fig. 6 Static load test. Loads were applied to the center of the mental region of the mandible.

tical bone $(F)$. In the case of the $F$ group, similar to the situation with the static load test, fast-setting adhesive resin cement was used to bond the fixture to the implant preparation in the bone. Occlusal and buccal views of the fixture implanted in the mandible are shown in Figs. 7 and 8 .

The impact force was imparted using an Izod test instrument modified by this department for use with impact fracture tests on the mandible (Fig. 9). The test was carried out by fixing the fixture frame for the test object with screws to the base plate of the impact fracture test apparatus. One side of the test mandible from the mental foramen to the ramus was then placed in quick-curing dental tray resin that had been inbedded into this frame. A hammer was then flung down on the center of the mental region of the test mandible, fracturing it. The test specimen was set up so that the head of the hammer at the time it reached the dead bottom (lowest) point was in the center of the mental region and parallel to the direction of the arrow on the mandible (Fig. 10).

The impact energy (E), i. e., the energy required for impact fracture, was computed by the formula

$$
\mathrm{E}=\mathrm{WR}(\cos \beta-\cos \alpha)
$$

where the angle $\alpha$ is the lift angle of the ham-

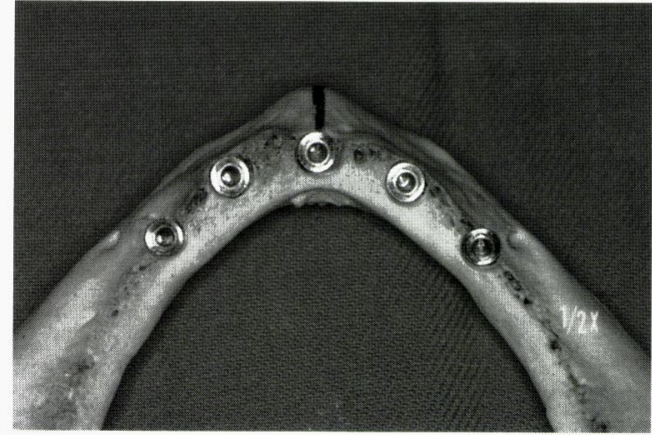

Fig. 7 Occlusal view of placement of the implant fixtures.

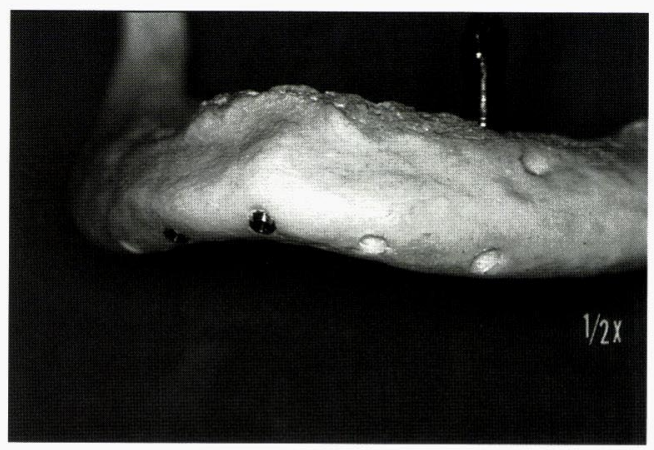

Fig. 8 Fixtures tightened into tapped bone sites.

mer $\left(180^{\circ}\right), \beta$ is the fling-up angle of the hammer after impact fracture, $\mathrm{W}$ is the hammer weight ( $1 \mathrm{~kg})$, and $\mathrm{R}$ is the distance between the pivot and the center of gravity of the hammer $(17 \mathrm{~cm})$. Therefore, $\mathrm{E}$ is actually obtained by measuring the fling-up angle of the hammer, $\beta$ (Table 1, Fig. 11). The averages were obtained from the values for the five mandibles in each group. These were taken as the measured values and were used in the statistical evaluations. At the same time the location of the fracture occurring in the test mandibles, i. e., the place of the impact fracture, was compared for each group. 


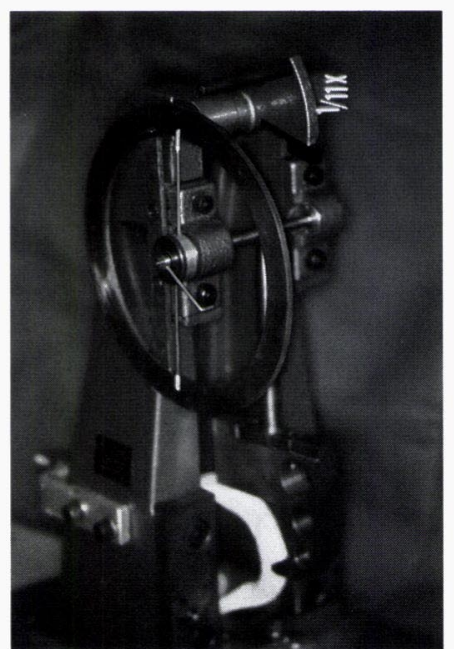

Fig. 9 Izod-type impact fracture test apparatus.

Table 1 Formula for calculating impact energy for the Izod-type impact fracture test apparatus

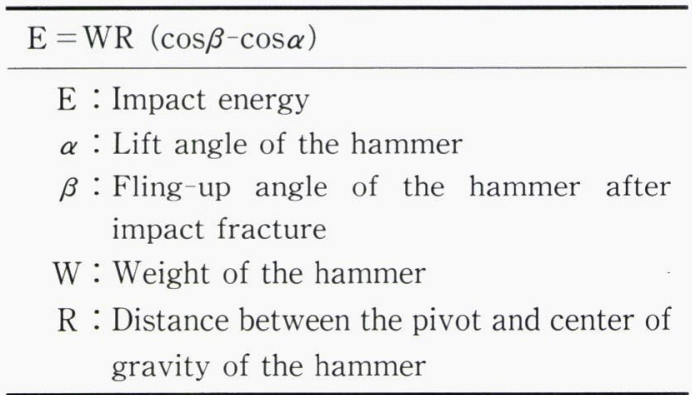

\section{Results}

\section{Static Load Test}

(1) Strain distribution in the P group (Figs. 12 and 13$)$

The strains on the buccal surfaces were compressive on both sides. The peak strains were seen in four locations: the premolar regions distal to the mental foramina on both sides (gauge numbers 1 and 24), and the anterior regions slightly distal to the load point (gauge numbers 10 and 15). The maximum value was

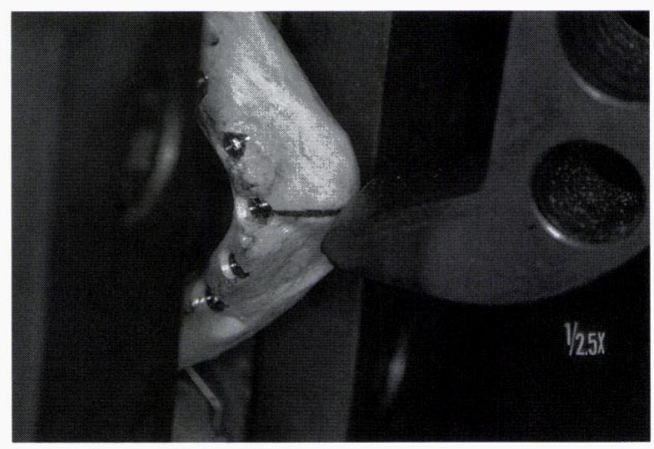

Fig. 10 Test mandible carefully placed to receive the impact force at the center of the mental region.

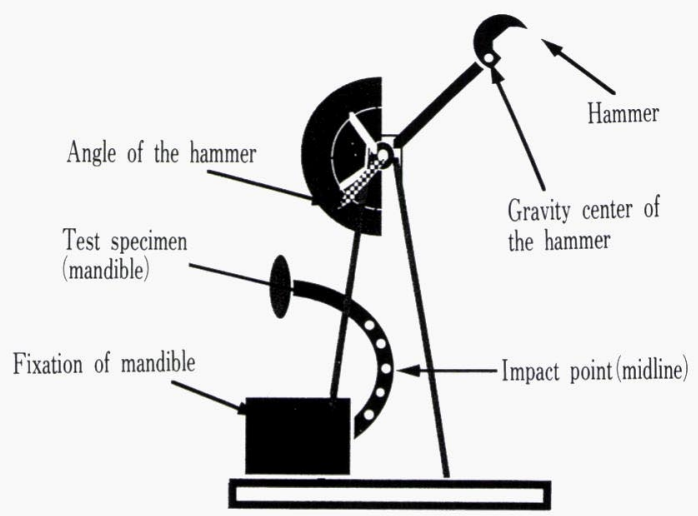

Fig. 11 Schematic diagram of the Izod-type impact fracture test apparatus.

$96 \mu$ strain at gauge number 15 . On the lingual surface, tensile strains were seen in the central region while compressive strains were measured towards the distal. The maximum value for the tensile strain was $160 \mu$ strain, while that for compressive strain was $110 \mu$ strain.

(2) Strain distribution in the M group (Figs.

\section{4 and 15}

Compared with the $\mathrm{P}$ group, the strain in the $\mathrm{M}$ group increased at all measurement points on the buccal surface and, with the exception of the value at gauge number 11 (174 $\mu$ strain), the region of peak strain was not as clear-cut as it was with the $\mathrm{P}$ group. On the lingual surface, the $M$ group had compressive strains in the central region and tensile strains towards the 


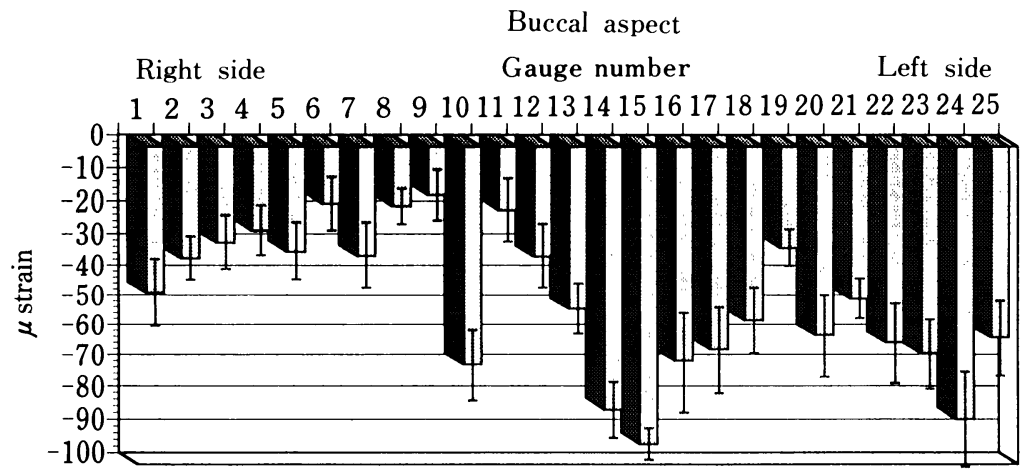

Fig. 12 Strain distribution under static loads on the buccal side of the edentulous mandible before preparation of drill holes.

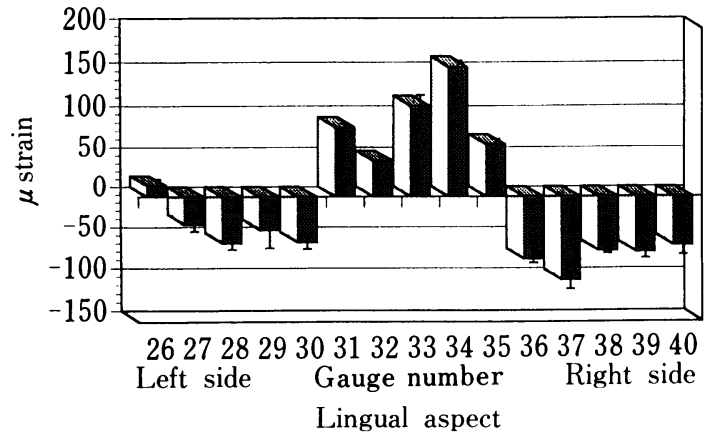

Fig. 13 Strain distribution under static loads on the lingual side of the edentulous mandible before preparation of the drill holes.

distal, and there were not such large variations in polarization of the strain distribution as was seen with the $\mathrm{P}$ group. However, there was a marked increase in the size of the strain in the central region, and a maximum value of 249 $\mu$ strain was measured at gauge number 30 . In contrast, the strain was lower towards the distal than in the anterior region.

(3) Strain distribution in the B group (Figs. 16 and 17)

On the buccal surface compressive strains were detected at all measurement points, and the increase in the strain was even greater than in the case of the M group. A value of 172 $\mu$ strain was detected at gauge number 10 , while the strain at gauge number 14 was $183 \mu$ strain. In addition, the difference in the size of the strain was more marked than for the M group, and a region appeared that had a definite peak. Furthermore, the appearance of this peak seemed to center around a drill hole preparation. On the lingual surface, the B group showed the same distribution as the $\mathrm{M}$ group in terms of degree and polarity of strain.

(4) Strain distribution in the F group (Figs. 18 and 19)

On both the buccal and lingual sides, the distribution of strain polarity was the same as for the B group. However, the magnitude was slightly decreased, with the maximum value being $178 \mu$ strain at gauge number 14 .

(5) Comparison of the strains in the $\mathrm{M}, \mathrm{B}$ and $\mathrm{F}$ groups with those in the $\mathrm{P}$ group (Fig. 20)

There was an increase in strain at virtually every measurement point. This was particularly marked on the buccal surface of the drill hole preparations, i. e., at gauge numbers 4, 6, 9 and 11 , where the increase was 4 to 9 fold. On the lingual surface, an increase in the strain was detected around the midline. This was particularly marked at gauge numbers 31,32 and 35 , where the rate of increase was 2 to 3 fold. 


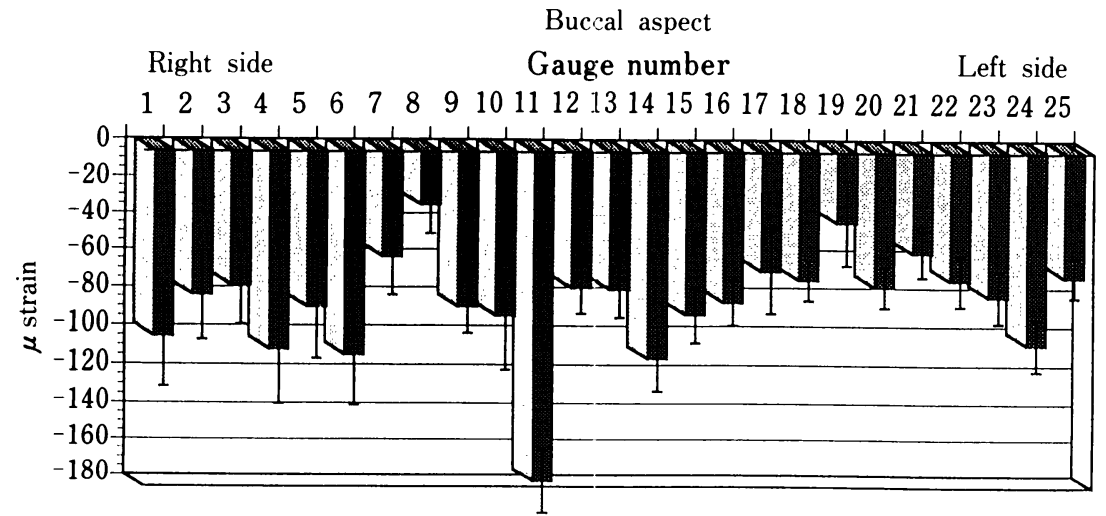

Fig. 14 Strain distribution under static loads on the buccal side of the edentulous mandible after monocortical implant preparation.

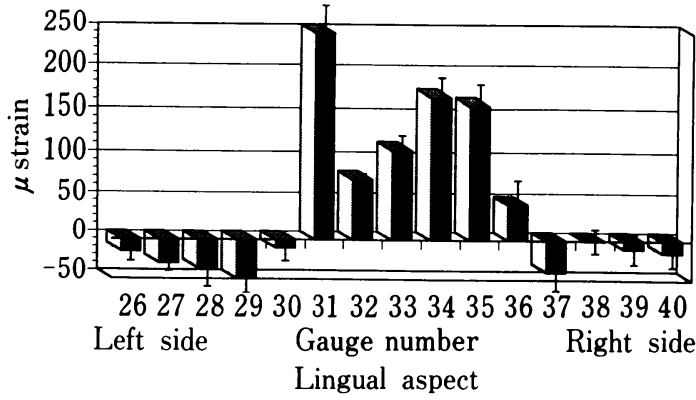

Fig. 15 Strain distribution under static loads on the lingual side of the edentulous mandible after monocortical implant preparation.

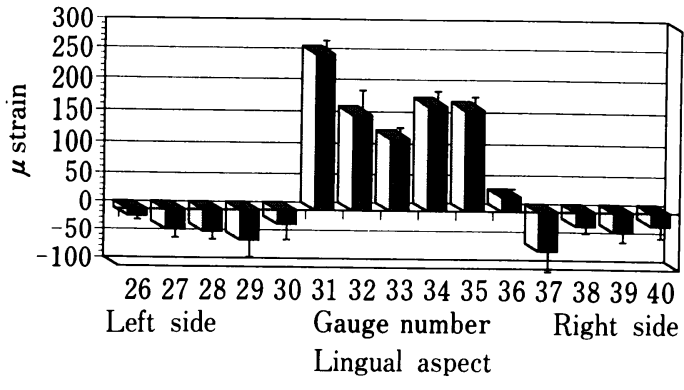

Fig. 17 Strain distribution under static loads on the lingual side of the edentulous mandible after bicortical implant preparation.

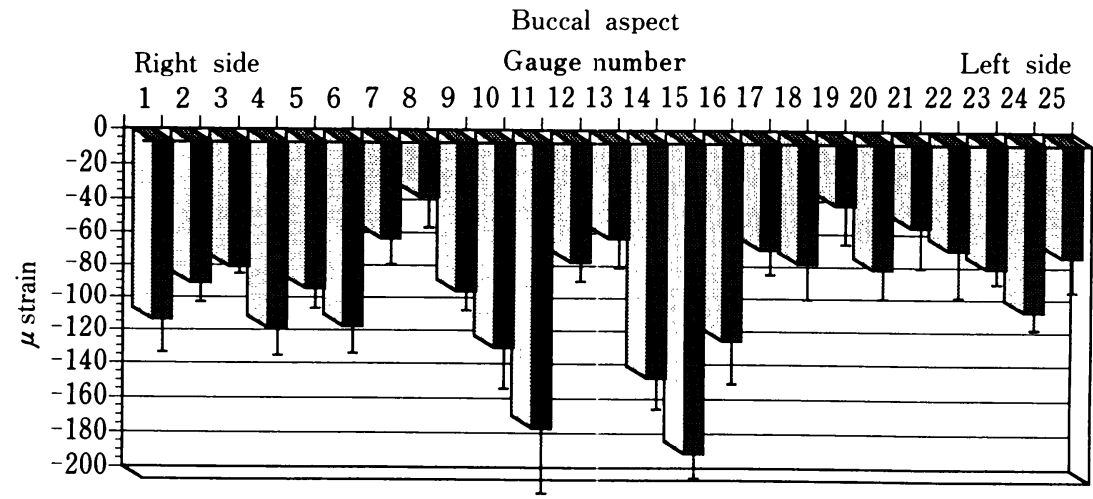

Fig. 16 Strain distribution under static loads on the buccal side of the edentulous mandible after bicortical implant preparation. 


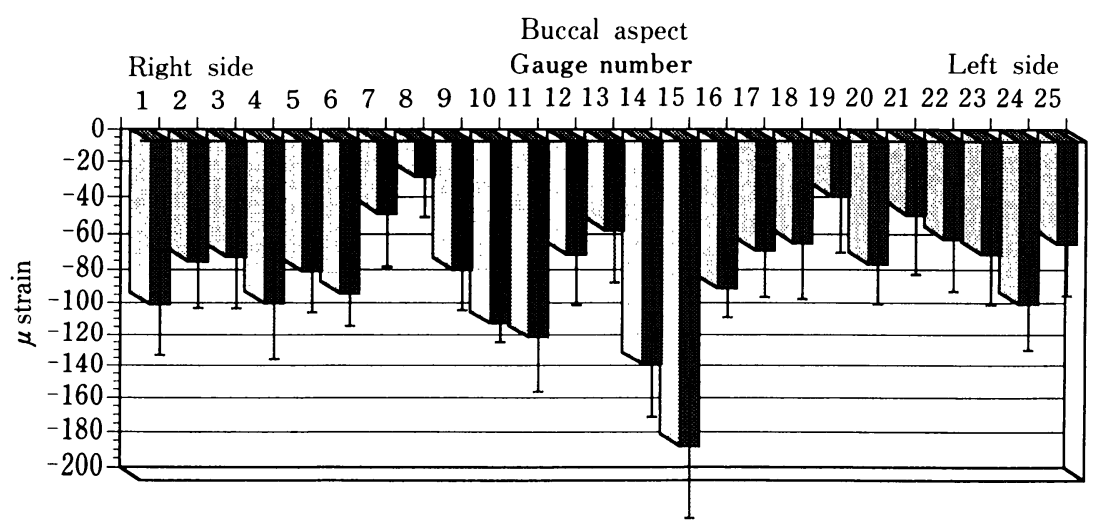

Fig. 18 Strain distribution under static loads on the buccal side of the edentulous mandible after placement of the implant fixtures in the bone.

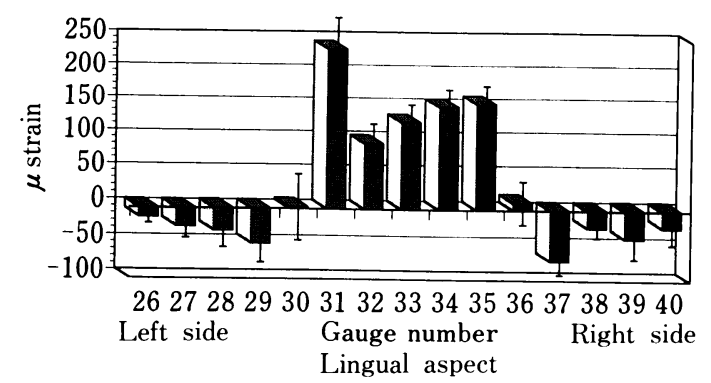

Fig. 19 Strain distribution under static loads on the lingual side of the edentulous mandible after placement of the implant fixtures in the bone.

However, in the distal region the strain reversed and decreased, with the ratio becoming less than 1.0. The B group had the largest strain, followed by the $\mathrm{F}$ group, for which the values were about the same. The rate of change for the $\mathrm{M}$ group was smaller than that for the $\mathrm{B}$ and $\mathrm{F}$ groups.

\section{Impact Fracture Test}

(1) Fling-up angle of the hammer (Table 2, Fig. 21)

The results for the fling-up angle of the hammer were $3.8^{\circ}$ for the $\mathrm{P}$ group, $14.1^{\circ}$ for the $\mathrm{M}$ group, $35.9^{\circ}$ for the $\mathrm{B}$ group, and $32.4^{\circ}$ for the $\mathrm{F}$ group. Thus the highest values were measured for the B group. Although no significant difference was found between the $\mathrm{B}$ and $\mathrm{F}$ groups when the values were compared for the four groups, there were significant differences between all other groups.

(2) Impact fracture values (Table 3, Fig. 22)

The impact fracture value, which is the impact energy required to break the mandible, was $33.95 \mathrm{~kg} / \mathrm{cm}$ for the P group, $33.43 \mathrm{~kg} / \mathrm{cm}$ for the M group, $30.72 \mathrm{~kg} / \mathrm{cm}$ for the B group, and $31.17 \mathrm{~kg} / \mathrm{cm}$ for the $\mathrm{F}$ group. Statistical analyses showed no significant differences between the $\mathrm{B}$ and $\mathrm{F}$ groups, although all other intergroup differences were significant.

(3) Location of the impact fracture (Fig. 23) Virtually all the fractures for the P (5 of 5) and $M$ ( 4 of 5) groups arose either at the angle of the mandible or around the ramus on the fixed side of the test specimen. In contrast, fractures in the B group most often arose around the implant preparation in the bone $(4$ of 5). The fractures that arose around the implant preparation in both the $\mathrm{B}$ and $\mathrm{F}$ groups were all in the second implant from the distal on the fixed side of the test specimen. 


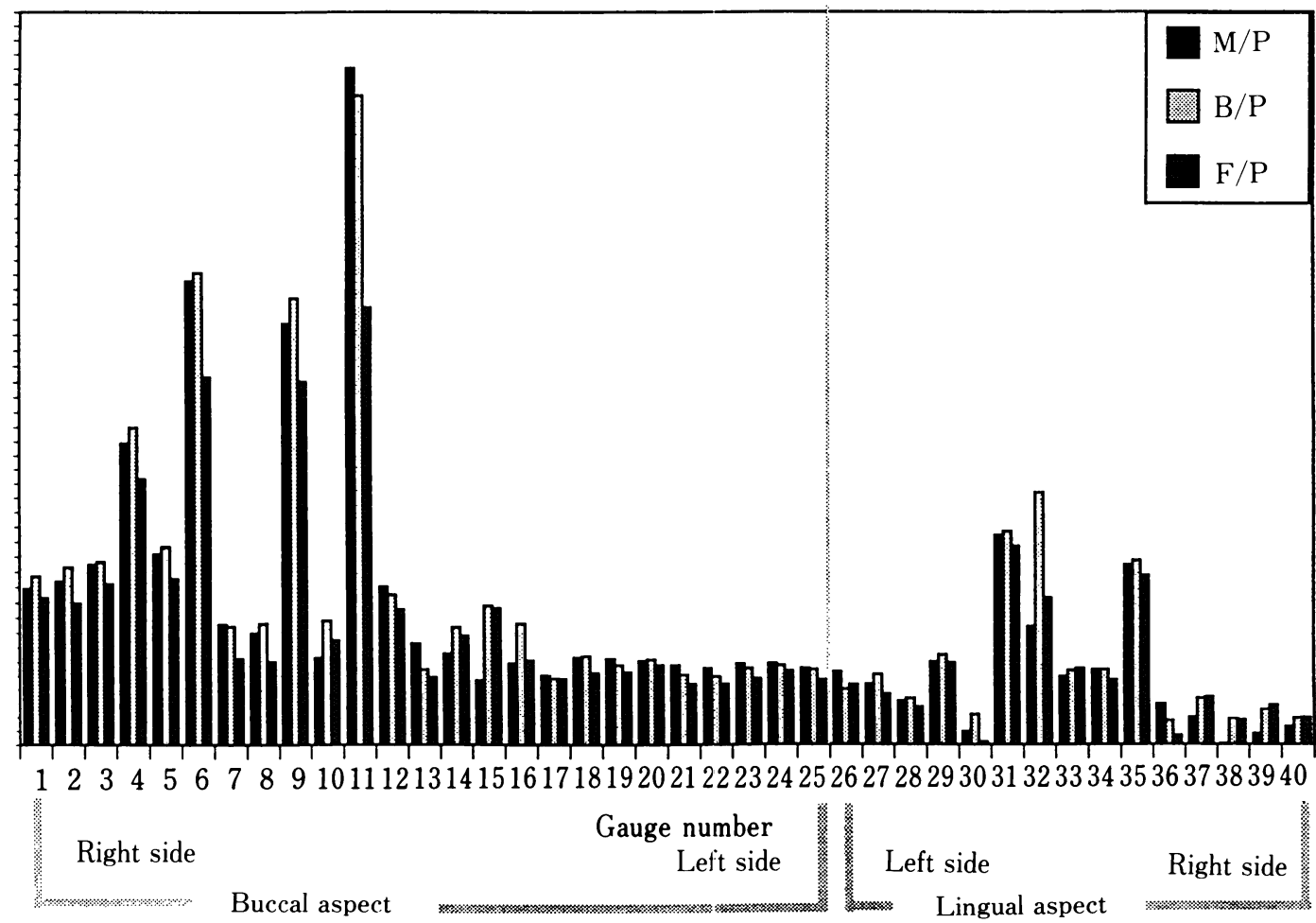

Fig. 20 Variations in strain after monocortical preparation $(/)$, bicortical preparation $(/)$, and placement of the fixtures $(/)$.

\section{Discussion}

Implant dentistry has in recent years received much attention as a method of improving cases where adequate restoration of masticatory function could not be attained by conventional removable prosthodontics. As a result of considerable basic research with animal experiments and investigations of clinical applications, implant dentistry has now acquired an important place in the prosthetic treatment of missing teeth.

Treatment methods for dental implants include intraosseous implants and subperiosteal implants as configurations for the support apparatus. Among the intraosseous implants, the Brånemark type in particular, which attains osseointegration through implantation in the jaw bones of screw type implants of high purity titanium, provides excellent clinical predictability. For this reason, its clinical application has seen growing popularity in recent years in Japan.

However, fractures of the jaw arising during the period of treatment following placement of the fixture have been reported as a complication of the screw type implant. These fractures may have occurred because this implant method was in the past often used even for cases associated with a high degree of alveolar ridge resorption, which is a contraindication, or where the placement of the fixture was in a region that readily created concentration of stresses in the mandibular anterior region. Also, fractures may have occurred because the defect in the bone resulting from placement of the implant created a mechanical weak point. 
Table 2 Comparison of the fling-up angles for the different groups with significance evaluated by the Mann-Whitney U test

\begin{tabular}{c|c|c|c}
\hline $\begin{array}{c}\text { Specimen } \\
(\text { Mean } \pm \mathrm{SD})\end{array}$ & $\begin{array}{c}\text { Monocortical } \\
(14.1 \pm 5.15)\end{array}$ & $\begin{array}{c}\text { Bicortical } \\
(35.9 \pm 5.59)\end{array}$ & $\begin{array}{c}\text { Fixture } \\
(32.4 \pm 10.38)\end{array}$ \\
\hline $\begin{array}{c}\text { Edentulous } \\
\text { mandible } \\
(3.8 \pm 2.86)\end{array}$ & $* * *$ & $*$ & $*$ \\
\hline $\begin{array}{c}\text { Fixture } \\
(32.4 \pm 10.38)\end{array}$ & $* *$ & N.S. & \\
\hline $\begin{array}{c}\text { Bicortical } \\
(35.9 \pm 5.59)\end{array}$ & $* *$ & & \\
\hline
\end{tabular}

(Degree)

Mann-Whitney U test

*** = significant $(\mathrm{p}<0.001)$

** = significant $(\mathrm{p}<0.01)$

$*$ significant $(\mathrm{p}<0.5)$

N. S. = not significant

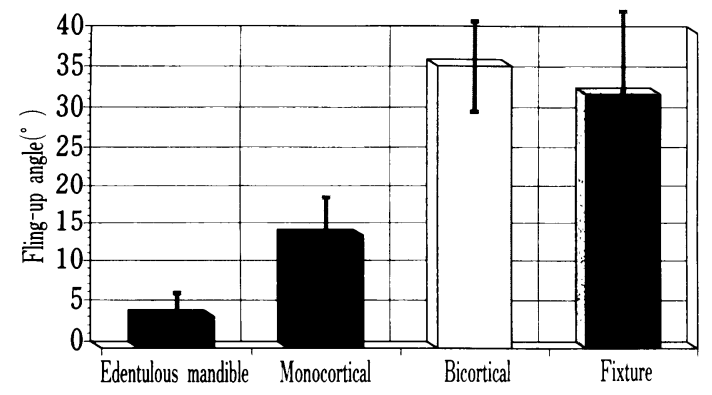

Fig. 21 Fling-up angle of the hammer after impact fracture of the test mandibles.

Although it has been recommended to avoid bicortical screwing and preserve the lower margin of mandibular bone, this conflicts with the fundamental clinical concept of desiring to attain strong initial fixation by making use of the upper and lower cortical bones, especially in cases where there is marked alveolar ridge resorption. However, there have been no reports of investigations into the mechanics of decreases in the strength of the mandible resulting from placement of implants. Therefore we planned and carried out this experiment to shed light on these issues.

The static load test was performed to understand changes in the strain distribution in the mandible, especially around implants, that result from preparation of the drill hole and placement of the fixture. First let us consider the results.

Measurement of the strain distribution in the edentulous mandible before preparation for the implant showed compressive strains throughout the buccal surface and on the lingual surface from the lateral mental region to the premolars. Tensile strains appeared only in the anterior region of the lingual surface. The magnitude of the tensile strain arising on the lingual surface was greater than the compressive strain measured in any other location. Consequently, when we consider the region of peak strain on the buccal side in the static load distribution patterns of this experiment, it seems that distortions arose that bent the mandibular arch inward, and that these distor- 
Table 3 Comparison of the Izod impact strengths for the different groups with significance evaluated by the Student's T test

\begin{tabular}{c|c|c|c}
\hline $\begin{array}{c}\text { Specimen } \\
(\text { Mean } \pm \mathrm{SD})\end{array}$ & $\begin{array}{c}\text { Monocortical } \\
(33.4 \pm 0.40)\end{array}$ & $\begin{array}{c}\text { Bicortical } \\
(30.7 \pm 0.99)\end{array}$ & $\begin{array}{c}\text { Fixture } \\
(31.2 \pm 1.63)\end{array}$ \\
\hline $\begin{array}{c}\text { Edentulous } \\
\text { mandible } \\
(34.0 \pm 0.08)\end{array}$ & $*$ & $* * *$ & $* *$ \\
\hline $\begin{array}{c}\text { Fixture } \\
(31.2 \pm 1.63)\end{array}$ & $*$ & N.S. & \\
\hline $\begin{array}{c}\text { Bicortical } \\
(30.7 \pm 0.99)\end{array}$ & $* * *$ & & \\
\hline
\end{tabular}

$(\mathrm{kg} \mathrm{cm})$

Student's T test

$$
\begin{aligned}
{ }^{* * *} & =\text { significant }(\mathrm{p}<0.001) \\
{ }^{* *} & =\text { significant }(\mathrm{p}<0.01) \\
{ }^{*} & =\text { significant }(\mathrm{p}<0.05)
\end{aligned}
$$

N. S. $=$ not significant

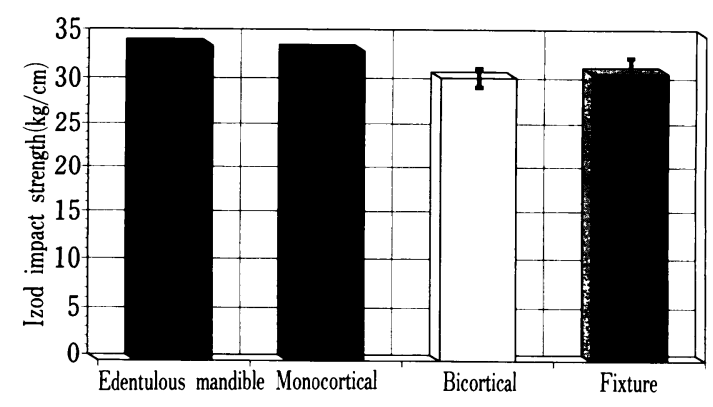

Fig. 22 Izod impact strength required to fracture the mandible.

tions centered around the lateral mental region and distal to the mental foramen near the load point on the buccal surface. This is the reason for large tensile stresses arising in the center of the lingual surface. Furthermore, since the strains were especially large on the lingual surface, it seems there is a greater possibility of distortions and fractures arising first in this region as a result of tensile stresses.

Compared with the strain for the $\mathrm{P}$ group, there was an increase in the compressive strain on the buccal surface in the $M$ group for all regions measured. However, on the lingual surface there was a decrease in the strain from the lateral mental region to the premolar region, and a marked increase in the tensile strain in the anterior region. Consequently, this suggests that the mandibular arch overall is more easily deformed as a result of the monocortical implant preparation, that tensile strains more readily concentrate on the lingual surface in particular, and that there is greater likelihood of fractures and distortions arising in the lingual anterior region.

The main feature of strain measurements in the $\mathrm{B}$ group was an increase in the compressive strain on the buccal surface near the implant preparation. This suggests that the effect of a bicortical implant preparation may readily extend to the buccal surface, and that compressive stresses originating on the buccal surface may easily result in distortions and fractures arising around the implant preparation. Furthermore, because the measured strains for the $\mathrm{F}$ group were all lower than those for the same region in the $B$ group, it seems that the 


\begin{tabular}{|c|c|c|c|}
\hline Fracture site & $\begin{array}{l}\text { Along to } \\
\text { implant hole }\end{array}$ & $\begin{array}{l}\text { Mandibular } \\
\text { angle }\end{array}$ & Ramus \\
\hline $\begin{array}{l}\text { Edentulous } \\
\text { mandible }\end{array}$ & 0 & 1 & 4 \\
\hline $\begin{array}{l}\text { Monocortically } \\
\text { drilled }\end{array}$ & 1 & 0 & 4 \\
\hline $\begin{array}{l}\text { Bicortically } \\
\text { drilled }\end{array}$ & 4 & 0 & 1 \\
\hline $\begin{array}{l}\text { Implant } \\
\text { installed }\end{array}$ & 2 & 0 & 3 \\
\hline
\end{tabular}

Fig. 23 Fracture site and number of specimens fractured at the location for the impact fracture test.

strength of the mandible somewhat improved, and that there was a tendency for a slight increase in resistance to external forces after placement of the fixture because of osseointegration between the surface of the implant and the bony wall of the implant preparation.

Summarizing the results of the above static load test, it is clear from strain comparisons that the bicortical implant preparation causes a greater decrease in resistance of the mandible to external forces than does the monocortical preparation. Furthermore, changes in the distribution of the strain polarity with the monocortical implant preparation showed that the increase in tensile strain occurred mainly around the center of the mandible on the lingual side. The mental region is considered an area of the mandible that under normal conditions has a predilection to fracture. It has been reported that the mechanism of occurrence of mandibular fractures is related to tensile stresses arising on the bone surface. These facts all suggest that the monocortical implant preparation has the potential to promote this type of fracture.

With the bicortical implant preparation, there is a marked increase in strains on the buccal surface, especially around the implant, rather than on the lingual surface. In addition to fractures resulting from tensile stresses on the lingual surface of the center of the mandible, it can also be anticipated that there is a high probability of fractures occurring because of compressive stresses from the buccal surface around the implant. Thus there is a tendency for some degree of improvement in strength when the fixture is placed and bonded to the bone with fast-setting adhesive resin cement. Also, it has been reported that a large number of post-operative fractures after implant operations arise during the healing phase before completion of osseointegration. These facts 
suggest that acquiring osseointegration has the potential of strengthening structural weaknesses that result from cross-sectional defects in the bone caused by preparation of the drill holes.

The results of the impact fracture test suggest that preparation of the mandible for implants causes a decrease in the impact fracture strength, that the degree of this decrease is more pronounced for the bicortical implant preparation than for the monocortical type, and that there is a slight improvement in strength following establishment of osseointegration. We found that compared with the small decrease in impact fracture strength of the mandible caused by the monocortical implant preparation, a marked decrease occurred with the bicortical type. Furthermore, comparison of the location of the fracture indicated that although the monocortical implant preparation did not greatly affect fracture location, the bicortical preparation often resulted in a break occurring around a drill hole in the anterior region.

From the above experimental results it seems necessary when using Brånemark implants in edentulous mandibles either to carry out bicortical implant preparations that preserve cortical bone on the lower margin of the mandible in cases where there is adequate bone height, and to avoid this type of preparation in cases with marked bone resorption, or to decrease the number of implants and not weaken the mandible. Avoiding implant preparations especially in the lateral mental region is also considered effective in cases like this to avoid iatrogenic fractures of the mandible. In addition, the presence of the digastric fossa on the lingual surface of the anterior region of the mandible causes a marked increase on strain on the buccal when there is a bicortical implant preparation in this region. Doctors tend to prepare the drill hole towards the buccal since they fear perforation of the implant in this region. With this in mind, it is necessary to prepare the drill hole accurately in the middle of the mandibular arch and to not allow the drilling to comprornise the cortical bone on the buccal or lingual.

\section{Conclusions}

From this study, the following conclusions when we carried out static load tests and impact fracture tests on edentulous mandibles to understand how implant preparations change the resistance of this bone to external forces.

1 ) Compared with the monocortical implant preparation, the bicortical preparation produced greater deterioration in resistance of the mandible to external forces, and in impact fracture strength. It also increased the possibility of fracture near the preparation.

2 ) These results suggest that fractures resulting from the bicortical implant preparation are most likely to occur in the lateral mental region.

We would like to express our profound gratitude to Professor Yoshiro Yamamoto, Director of the First Department of Oral Surgery, Meikai University, School of Dentistry for his kind guidance throughout preparation of this manuscript. We would also like to thank the doctors and staff of the department for their assistance.

\section{References}

1) Brånemark, P-I. : Osseointegration and its experimental background. J. Prosthet. Dent., $50: 399-410,1983$

2) Brånemark, P-I. : Intraosseous anchorage of dental prostheses: I . Experimental studies. Scand. J. Plast. Reconstr. Surg., 3:81-100, 1969.

3) Hannsson, H-A., Albreksson, T. and Brånemark, P-I. : Structural aspects of the interface between tissue and titanium implants. J. Prosthet. Dent., 50 : 108-113, 1983.

4) Adell, R. : A 15-year study of osseointegrat- 
ed implants in the treatment of the edentulous jaw. Int. J. Oral Surg., $6: 387,1981$.

5) Brånemark, P-I. : Osseointegrated implants in the treatment of the edentulous jaw : Experience from a 10-year period. Scand. J. Plast. Reconstr. Surg., 16 (Suppl) : 1977.

6) Adell, R. : Marginal tissue reactions at osseointegrated titanium fixtures: I . A threeyear longitudinal prospective study. Int. J. Oral Surg., 1985.

7) Adell, R. : Clinical results of osseointegrated implants supporting fixed prostheses in edentulous jaws. J. Prosthet. Dent., $50: 251$, 1983.
8) Masson, M. E., Triplett, R. G. and Van Sickles, J. E. : Mandibular fractures through endosseous cylinder implants: Report of cases and reviews. J. Oral Maxillofac. Surg., $48: 311,1990$.

9) Beumer, J. and Lewis, S. G. : The Brånemark implant system : Clinical and laboratory procedures. 31-109, Ishiyaku Euro America (St. Louis), 1989.

別刷請求先：河津 寛, 嶋田 淳

\title{
無歯下顎骨の衝撃破折強度に及ぼすインプラント体植立の 影響についての研究
}

\author{
河津寛嶋田淳
}

従来の可撤性補綴物にかわり，近年インプラント療法が注目され，多くの基礎的研究や臨床応用による 調査を経て，現在では歯科医学領域において欠損補綴治療の重要な位置を占めるところとなった。

一方，特に歯根型のインプラントを下頡骨に植立した場合に，インプラント床形成部の下顎骨に偶発骨 折の発生した報告がある。これは数ミリメートルの直径を有するインプラントを埋入するにあたり，骨に 円筒状の骨孔をドリリングするため, 結果としてその骨実質に欠損を与えることになり，本来下䫕骨に備 わっていた強度を低下させたために生じたものとされている。

しかし，このインプラント体植立による下額骨の強度低下について力学的に検討した報告はみあたらな い. そこで筆者らは, 無歯下顎骨を材料として, これに歯根型インプラントである Brånemark インプラン 卜を植立した場合の衝撃破折強度に及ほす影響について, 印欧系の無歯下頻骨 25 体にインプラントを埋入 し静的荷重負荷試験, および衝撃破折試験を行い研究を行ったところ, 次の結果が得られた。

1) Bicortical なインプラント床の形成は monocortical なインプラント床の形成に比較して,下顎骨の 外力に対する抵抗性および衝撃破折強度に大きな影響を及ぼし，インプラント床形成部付近における骨折 発生の可能性を高める.

2 ) Bicortical なインプラント床の形成による骨折の発生はオトガイ部に出現しやすいことが示唆された. 